\title{
A Critical Review of Machine Loading Problem in Flexible Manufacturing System
}

\author{
Ranbir Singh', Rajender Singh ${ }^{2}$, B. K. Khan ${ }^{3}$ \\ ${ }^{1}$ Research Scholar, Department of Mechanical Engineering, DCRUST Murthal, Sonepat, India \\ ${ }^{2}$ Professor, Department of Mechanical Engineering, DCRUST Murthal, Sonepat, India \\ ${ }^{3}$ Technical Advisor, MSIT, Sonepat, India \\ Email: ranbirsheoran@gmail.com
}

Received 16 January 2015; accepted 27 November 2015; published 30 November 2015

Copyright (C) 2015 by authors and Scientific Research Publishing Inc.

This work is licensed under the Creative Commons Attribution International License (CC BY). http://creativecommons.org/licenses/by/4.0/

(c) †) Dpen Access

\begin{abstract}
Production planning is the foremost task for manufacturing firms to deal with, especially adopting Flexible Manufacturing System (FMS) as the manufacturing strategy for production seeking an optimal balance between productivity-flexibility requirements. Production planning in FMS provides a solution to problems regarding part type selection: machine grouping, production ratio, resource allocation and loading problem. These problems need to be solved optimally for maximum utilization of resources. Optimal solution to these problems has been a focus of attention in production and manufacturing, industrial and academic research since a number of decades. Evolution of new optimization techniques, software, technology, machines and computer languages provides the scope of a better optimal solution to the existing problems. Thus there remains a need of research to solve the problem with latest tools and techniques for higher optimal use of available resources. As an objective, the researchers need to reduce the computational time and cost, complexity of the problem, solution approach viz. general or customized, better user friendly communication with machine, higher freedom to select the desired objective(s) type(s) for optimal solution to the problem. As an approach to the solution to the problem, a researcher first needs to go for an exhaustive literature review, where the researcher needs to find the research gaps, compare and analyze the tools and techniques used, number of objectives considered for optimization and need, and scope of research for the research problem. The present study is a review paper analyzing the research gaps, approach and techniques used, scope of new optimization techniques or any other research, objectives considered and validation approaches for loading problems of production planning in FMS.
\end{abstract}

\section{Keywords}

Flexible Manufacturing Systems (FMS), Machines Loading, Loading Objectives, Production Planning, Optimization 


\section{Introduction}

Manufacturing is the pilot element within the overall enterprise. Possible manufacturing outputs of the firm to meet pre-determined corporate level goals should be known to remain in competition at global market. Manufacturing strategy writes the script to calculate possible manufacturing outputs. Existence of the manufacturing strategy guides daily decisions and activities with clear understanding of decision-goal relationship of the corporation and provides a vision for the firm to remain aligned with the overall business strategy of the firm. The firms having manufacturing strategies for achieving corporate goals survive for long run. A strategy is also a strong communication tool between different levels of management to bring all operations in line with corporate objectives. Custom manufacturing, continuous manufacturing, intermittent manufacturing, flexible manufacturing, just-in-time manufacturing, lean manufacturing and agile manufacturing are major manufacturing strategies revealed in the literature.

FMS is an automated manufacturing system consisting of computer numerical control (CNC) machines with automated material handling, storage and retrieval system. The aim of FMS is to attain the efficiency of mass production while utilizing the flexibility of job shop simultaneously. FMS is adopted for batch production of mid production volume and mid part variety (flexibility) requirements. Since its evolution, researchers are working for optimality of FMS strategy. FMS is a field of great potential hence a numerous complex planning problems need to be solved. Major complex production planning problems are part type selection: machine grouping, production ratio, resource allocation and loading problem (Stecke, 1983). All the production planning problems need to be optimally solved. The present research is the critical literature review for the loading problem of production planning in FMS.

Tooling individual or group of machine(s) to collectively accomplish all manufacturing operations concurrently for all part type in a batch is termed as loading problem. A solution to the problem specifies the machine(s) to which a job has to be routed in sequence for each of its operation(s) with respective tooling under capacity and technological constraint(s) for all jobs in a batch simultaneously to achieve certain objective(s). Loading is a complex combinational planning problem because a batch of jobs is to be machined simultaneously and each job requires unique set of operations effect on manufacturing cost.

To solve the problem, highly experienced and skilled professionals are required. Without the use of some computational or optimization technique, the solution may or may not be optimal. Thus there arises the need of optimal solution with the help of computational methods using optimization techniques. The paper is a critical review paper analyzing the research gaps, approach and techniques used, scope of new optimization techniques or any other research, objectives considered and validation approaches for loading problems of production planning in FMS.

\section{Literature Review of Loading Problems in FMS}

In brief, to solve a problem using optimization techniques and computational analysis, objective(s) are first set, the physical system is modelled using certain technique like mathematical modelling, the solution is then derived under given boundary conditions and constraints to achieve the given objectives, the results are then analysed and the solution approach is then validated. Heuristics has been widely used by the researchers. Table 1 presents the tabulated research review discussing the approach, objectives and results of the loading problems in FMS. Flexible manufacturing is an overall pilot element within an enterprise. Each multinational manufacturing concern has to satisfy business goals to remain in competition with the global market. The manufacturing firm should be aware of the possible manufacturing outputs that will closely match the goals and strategy determined at the corporate level. The existence of a manufacturing strategies guide the daily decisions and activities with clear understanding of how those daily decisions relate to the overall goals of the corporation. The firms having manufacturing strategies for achieving corporate goals survive long. A manufacturing strategy provides a vision to the manufacturing organization for keeping itself aligned with the overall business strategy of the corporation. A strategy is also a strong communication tool between different levels of management to bring all operations in line with corporate objectives. Custom manufacturing, continuous manufacturing, intermittent manufacturing, flexible manufacturing, just-in-time manufacturing, lean manufacturing and agile manufacturing are the major manufacturing strategies which are revealed in literature.

FMS is an automated manufacturing system consisting of numerical control (computer) machines with automated material handling, automated storage and retrieval system. The aim of FMS is to attain the efficiency of 
Table 1. Review of machine loading problems in FMS based on heuristics approach.

\begin{tabular}{|c|c|c|c|c|c|c|c|}
\hline \multicolumn{8}{|c|}{ HEURISTIC APPROACH } \\
\hline Sr. & Year & Researcher Name & Approach & & Objectives & Results & Validation approach \\
\hline 1 & 1983 & $\begin{array}{l}\text { K. E. Stecke \& F. } \\
\text { Brian Talbot [2] }\end{array}$ & $\begin{array}{l}\text { Heuristic } \\
\text { methods }\end{array}$ & $\begin{array}{l}> \\
>\end{array}$ & $\begin{array}{l}\text { Minimizing part movements } \\
\text { Balancing of workload } \\
\text { Unbalancing of workload }\end{array}$ & $\begin{array}{l}\text { Determined how machine } \\
\text { tool magazine in a FMS can } \\
\text { be loaded to meet } \\
\text { simultaneous requirements of } \\
\text { a number of different parts }\end{array}$ & $\begin{array}{l}\text { Computational results are } \\
\text { presented }\end{array}$ \\
\hline 2 & 1985 & $\begin{array}{c}\text { K. Shankar \& Y. J. } \\
\text { Tzen [14] }\end{array}$ & $\begin{array}{l}\text { Heuristic } \\
\text { methods }\end{array}$ & $>$ & $\begin{array}{l}\text { Minimizing system unbalance } \\
\text { Number of late jobs } \\
\text { Balancing of workload }\end{array}$ & $\begin{array}{l}\text { Computational results } \\
\text { presented gives } \\
\text { improved results }\end{array}$ & $\begin{array}{c}\text { performance is compared } \\
\text { with previous results from } \\
\text { literature }\end{array}$ \\
\hline 3 & 1988 & $\begin{array}{l}\text { J. A. Ventura, F. F. } \\
\text { Chen, \& M. S. } \\
\text { Leonard [15] }\end{array}$ & $\begin{array}{l}\text { Heuristic } \\
\text { algorithms }\end{array}$ & $>$ & Minimizing make span & Improved Performance & $\begin{array}{l}\text { The performance of each of } \\
\text { the proposed algorithms is } \\
\text { evaluated by testing on two } \\
\text { hypothetical FMSs. }\end{array}$ \\
\hline 4 & 1990 & $\begin{array}{l}\text { B. Ram, S. Sarin, \& } \\
\text { C. S. Chen [16] }\end{array}$ & $\begin{array}{c}\text { Fast heuristic } \\
\text { algorithms }\end{array}$ & $>$ & Maximizing throughput & $\begin{array}{l}\text { FMS loading problem can be } \\
\text { solved near optimally in } \\
\text { short time }\end{array}$ & $\begin{array}{l}\text { e Computational results are } \\
\text { produced and compared } \\
\text { with previous results }\end{array}$ \\
\hline 5 & 1992 & $\begin{array}{l}\text { S. K. Mukhopadhyay, } \\
\text { S. Midha, \& V. } \\
\text { Murlikrishna [17] }\end{array}$ & $\begin{array}{l}\text { Heuristic } \\
\text { procedure }\end{array}$ & $>$ & $\begin{array}{l}\text { Minimizing system unbalance } \\
\text { Maximizing throughput }\end{array}$ & $\begin{array}{l}\text { Results show that algo } \\
\text { developed is very reliable } \\
\text { and efficient }\end{array}$ & $\begin{array}{l}\text { tested on ten problems and } \\
\text { are compared with existing } \\
\text { results }\end{array}$ \\
\hline 6 & 1993 & $\begin{array}{l}\text { K. Kato, F. Oba, \& F. } \\
\text { Hashimoto [18] }\end{array}$ & $\begin{array}{l}\text { Heuristic } \\
\text { approach }\end{array}$ & $>$ & $\begin{array}{l}\text { Minimizing total number of } \\
\text { cutting tools required } \\
\text { Maximizing utilization rate of } \\
\text { each machine }\end{array}$ & $\begin{array}{l}\text { Computational results shows } \\
\text { improved effectiveness }\end{array}$ & $\begin{array}{l}\text { Computational results are } \\
\text { given to demonstrate the } \\
\text { effectiveness of the } \\
\text { proposed method }\end{array}$ \\
\hline 7 & 1995 & $\begin{array}{l}\text { E. K. Steeke \& F. } \\
\text { Brian Talbot [19] }\end{array}$ & $\begin{array}{l}\text { Heuristic } \\
\text { Algorithms }\end{array}$ & $>$ & $\begin{array}{l}\text { Minimizing part movements } \\
\text { balancing of workload } \\
\text { unbalancing of workload }\end{array}$ & $\begin{array}{l}\text { Results are computationally } \\
\text { demonstrated \& found } \\
\text { improved significantly }\end{array}$ & $\begin{array}{l}\text { Computational results are } \\
\text { produced and compared } \\
\text { with previous results }\end{array}$ \\
\hline 8 & 1997 & $\begin{array}{l}\text { M. K. Tiwari } \\
\text { et al. [20] }\end{array}$ & $\begin{array}{l}\text { Heuristic } \\
\text { solution } \\
\text { approach }\end{array}$ & $>$ & $\begin{array}{l}\text { Maximizing throughput } \\
\text { Minimizing system unbalance }\end{array}$ & $\begin{array}{l}\text { Graphical representation and } \\
\text { subsequent model validation }\end{array}$ & $\begin{array}{l}\text { Computational results are } \\
\text { produced and compared } \\
\text { with previous results }\end{array}$ \\
\hline 9 & 1998 & $\begin{array}{l}\text { G. K. Nayak \& D. } \\
\text { Acharya [21] }\end{array}$ & $\begin{array}{c}\text { Heuristics and } \\
\text { mathematical } \\
\text { programming } \\
\text { approaches }\end{array}$ & $>$ & $\begin{array}{l}\text { Maximizing part types in each } \\
\text { batch } \\
\text { Maximizing routing flexibility } \\
\text { of batches }\end{array}$ & $\begin{array}{l}\text { Heuristic proposed for part } \\
\text { type selection \& simple } \\
\text { mathematical programs for } \\
\text { other two problems }\end{array}$ & $\begin{array}{l}\text { Computational results are } \\
\text { compared with existing } \\
\text { results }\end{array}$ \\
\hline 10 & 2000 & $\begin{array}{l}\text { D.-H. Lee \& Y.-D. } \\
\quad \text { Kim [22] }\end{array}$ & $\begin{array}{l}\text { Heuristic } \\
\text { algorithms }\end{array}$ & $>$ & $\begin{array}{l}\text { Minimizing maximum } \\
\text { workload of machines }\end{array}$ & $\begin{array}{l}\text { Results show that suggested } \\
\text { algos perform better than } \\
\text { existing }\end{array}$ & $\begin{array}{c}\text { Simulation results are } \\
\text { compared with existing } \\
\text { results }\end{array}$ \\
\hline 11 & 2006 & $\begin{array}{l}\text { N. Nagarjunaa, O. } \\
\quad \text { Maheshb, \& } \\
\text { K. Rajagopal [23] }\end{array}$ & $\begin{array}{l}\text { Heuristic } \\
\text { based on multi } \\
\text { stage } \\
\text { programming } \\
\text { approach }\end{array}$ & & $\begin{array}{l}\text { Minimizing system } \\
\text { unbalance }\end{array}$ & $\begin{array}{l}\text { Bring together } \\
\text { productivity of flow lines } \\
\text { and flexibility of job shops }\end{array}$ & $\begin{array}{c}\text { Tested on } 10 \text { sample } \\
\text { problems available in FMS } \\
\text { literature and compared } \\
\text { with existing solution } \\
\text { methods }\end{array}$ \\
\hline 12 & 2006 & $\begin{array}{l}\text { M. Goswami \& M. } \\
\text { K. Tiwari [24] }\end{array}$ & $\begin{array}{l}\text { Heuristic-based } \\
\text { approach }\end{array}$ & $>$ & $\begin{array}{l}\text { Minimizing system unbalance } \\
\text { Maximizing throughput }\end{array}$ & $\begin{array}{l}\text { Loading problem is crucial } \\
\text { link between tactical } \\
\text { planning and operational } \\
\text { decisions }\end{array}$ & $\begin{array}{l}\text { Extensive computational } \\
\text { experiments have been } \\
\text { carried out to assess the } \\
\text { performance of the } \\
\text { proposed heuristic and } \\
\text { validate its relevance }\end{array}$ \\
\hline 13 & 2007 & $\begin{array}{l}\text { M. K. Tiwari, J. Saha, } \\
\text { \& S. K. } \\
\text { Mukhopadhyay } \\
{[25]}\end{array}$ & $\begin{array}{l}\text { Heuristic } \\
\text { Solution } \\
\text { Approaches }\end{array}$ & $>$ & $\begin{array}{l}\text { Minimizing system unbalance } \\
\text { Maximizing throughput }\end{array}$ & $\begin{array}{l}\text { GA based heuristic are found } \\
\text { more efficient and } \\
\text { outperform in terms of } \\
\text { solution quality }\end{array}$ & $\begin{array}{l}\text { tested on problems } \\
\text { representing three different } \\
\text { FMS scenarios from } \\
\text { available literature }\end{array}$ \\
\hline
\end{tabular}

mass production while utilizing the flexibility of job shop simultaneously. Most of the researches are focused on increasing the production volume of FMS with increased part varieties. FMS is an interesting field of research to solve the issues and problems encountered by industries. Though FMS has great potential benefits, a numerous 
control and planning problem need to be taken care of. Kathryn E. Stecke in 1983 described five complex productions planning problems namely part type selection problem, Machine Grouping Problem, production ratio problem, resource allocation problem and loading problem [1].

Loading means allocation of the operations and required tools to a part types among the set of machine(s), subjected to resource \& technological constraints to collectively accomplish all manufacturing operations for each pat type machined concurrently. The allocation of workloads to the existing production facilities for manufacturing products with several constraints in order to perform production activities according to the production plan established, it is essential to adjust the workload for each of the facilities and workers in each time period so they are not assigned work exceeding the given capacity. A solution to this problem specifies the tools which must be loaded in each machine tool magazine and the machine(s) to which a part can be routed for each of its operations before production begins. A variety of products are manufactured simultaneously in FMS, where each part requires potentially unique set of operations, and loading problem is declared as a combinational problem by Kathryn E. Stecke [2] which is highly complex, time-consuming and tedious in nature \& requires highly experienced process planners.

Machine loading is one of the most critical production planning problems of FMS. It concerns with the time spend by the job(s) on machine(s) and the manufacturing cost. Manufacturing cost is the sum of fixed and variable costs. Variable cost varies with the level of production output. As output increases, variable cost increases. Once invested, we can't play around the fixed cost; hence to reduce the manufacturing cost, researcher has to minimize the variable cost while maximizing the output. This is done by developing and optimizing a virtual model of manufacturing by some conventional or non-conventional technique for certain number of objectives with their individual weightage accordingly. A researcher has to solve the manufacturing model to minimize the time spent by the job on machine, number of tool used, and movements of tool and job. FMS is a group technology concept hence all the operations on the group jobs are required to be completed at once keeping in view that no machine should be idle or overloaded at any instance of time. Thus the optimized solution of the machine loading problem for certain objectives under technological and capacity constraints is required. The solution to the machine loading problem is to minimize the manufacturing cost as a whole.

Increasing part varieties with raised productivity is necessary to be in competition and to maintain the demand of the product, which is possible by continuous research and optimized solutions to each of the production planning problem. This paper presents a research review of the optimization techniques and the objectives for which the machine loading problem in FMS has been solved, and scope of the research in the field.

Before presenting literature review, an introduction to the optimization techniques and their classification seems necessary to be discussed here for better understanding of the subject. Optimization is the approach for ideal solution. Accuracy of the solution depends on the approach, modeling, computational time and capacity, and nature of the problem. Optimization is classified into six categories: function, and trial and error, single variable and multiple variables, static and dynamics, continuous and discrete, constrained and unconstrained, and random and minimum seeking.

A functional optimization is for theoretical approach where a mathematical formula describes the objective function. Trial-and-error optimization is for experimental optimization with change in the variables which affect output without knowing much about the process. An optimization can be single variable for one dimensional analysis, and multi variables for multi-dimensional analysis. As the number of variables increases, the complexity of the problem also increases. Static optimization is independent of time and dynamic optimization as a function of time. Discrete optimization has a finite number of variables with all possible values, while continuous optimization has infinite number of variables with all possible values. Values are incorporated in equalities and inequalities to an objective of variable function in constrained optimization while the variables can take any value in unconstrained optimization. Random optimization finds sets of variables by probabilistic calculations while minimal seeking is the traditional optimization algorithms which are generally based on calculus methods and minimizes the function by starting from an initial set of variable values.

These optimization approaches can be further sub-categorized as stochastic programming, integer programming, linear programming, nonlinear programming, bound programming, network programming, least squares methods, global optimization, and non-differential optimization.

Most of the researches are focused on solving the machine loading problem by global optimization algorithms. Global optimization algorithms are generally categorized into two approaches: deterministic and probabilistic. Deterministic are sub-categorized into static space search (1992) [3], branch and bond and algebraic geometry 
algorithms. Probabilistic is sub-categorized as Monte Carlo algorithms, soft computing and Artificial Intelligence (AI). Monte Carlo algorithms includes two classes, one covers Stochastic (hill climbing) (2002) [4], Random optimization (1963) [5], Simulated Annealing (SA) (1953) [6], Tabu Search (TS) (1989) [7], Parallel tempering, Stochastic tunneling and Direct Monte Carlo Sampling, and second class includes Evolutionary Computation (EC). EC can be performed by Monte Carlo algorithms or soft computing or AI. EC is further classified as Evolutionary Algorithms (EA), Memetic Algorithms (hybrid Algorithms) (1989) [8], Harmonic Search (HS), Swarm Intelligence (SI). EA is sub-classified as Genetic Algorithms (GA) (1962) [9], Learning Classifier System (LCS) (1977) [10], Evolutionary Programming, Evolution Strategy (ES), Genetic Programming (GP) (1958) [11]. ES includes Differential Evolution (DE), and GP includes Standard GP, Linear GP and Grammar Guided GP. SI includes Ant Colony Optimization (ACO) (1996) [12] and Particle Swarm Optimization (PSO) (1995) [13]. The above discussed classifications scheme will be used for classifying the optimization techniques for solving the machine loading problems of FMS in the paper. Figure 1 shows the evolution of the major optimization techniques along the time axis.

\section{Literature Review of Machine Loading Problems in FMS}

An exhaustive research review has been carried out for study of approaches and optimization techniques for machine loading problems in FMS. A. Baveja, A. Jain, A. K. Singh, A. Kumar, A. M. Abazari, A. Murthy, A. Prakash, A. Srinivasulu, A. Turkcan, C. A. Yano, C. Basnet, C.S. Chen, D. Acharya, D. Kosucuoglu, D.H. Lee, F. Brian Talbot, F. F. Chen, F. Guerrero, F. Hashimoto, F. Oba, G. K. Nayak, G.C. Lee, H. C. Co, H. Sattari, H. Yong, H.B. Jun, H.-K. Roh, J. A. Ventura, J. Larranaeta, J. S. Biermann, J. Saha, J. G. Shanthikumar, J. N. D. Gupta, K Chandrashekara, K. E. Stecke, K. Kato, K. M. Bretthauer, K. Rajagopal, K. Shankar, L. H. S. Luong, L. S. Kiat, M. A. Gamila, M. A. Venkataramanan, M. Arıkan, M. Berrada, M. Goswami, M. I. Mgwatua, M. K. Pandey, M. K. Tiwari, Ming Liang, M. M. Aldaihani, M. S. Akturk, M. S. Leonard, M. Savsar, M. Solimanpur, M. Yogeswaran, N. K. Vidyarthi, N. Khilwani, N. Kumar, N. Nagarjunaa, N. K. Vidyarthi, O. Maheshb, Prakash, R. P. Sadowski, R. Budiarto, R. D. Matta, R. H. Storer, R. M. Marian, R. R. Kumar, R. Shankar, R. Swarnkar, S. Biswas, S. Deris, S. Erol, S. G. Ponnambalam, S. K. Mandal, S. K. Mukhopadhyay, S. Kumar, S. Lozano, S. Midha, S. Motavalli, S. P. Dutt, S. Rahimifard, S. S. Mahapatra, S.C. Sarin, S.K. Chen, S.K. Lim, S.T. Newman, T. J. Greene, T. J. Sawik, T. Koltai, T. L. Morin, T. Sawik, U. Bilge, U. K. Yusof, V. H. Nguyen, V. M Kumar, V. Murlikrishna, V. N. Hsu, V. Tyagi, W. F. Mahmudy, Y. Cohen, Y. D. Kim, Y. J. Tzen and Z. Wu are key researchers for solving the loading problem of production planning in FMS.

The tabulated research review discussing the approach, objectives, results and validation approach for machine loading problems in FMS is discussed in Tables 1-3. The literature review is classified into three groups: (1) heuristics; (2) global optimization; and (3) other optimization techniques.

Table 1 presents the review of machine loading problems of FMS based on heuristics approach. The heuristics approach has been significantly used for solving the research problem. Research has gained significant acceleration with the evolution and growth of global optimization techniques.

Table 2 presents the review of machine loading problems in FMS based on global optimization algorithms. Global optimization techniques have been explored rigorously by the researchers. The natural selection techniques have reported good results compared to others. The application of global optimization techniques for solving machine loading problem is increasing with growth of natural optimization techniques. The results reported by natural optimization techniques are more acceptable. Natural optimization techniques, GA and PSO are widely used techniques.

Table 3 presents the review of machine loading problems in FMS based on optimization techniques not falling in the above classification. Since the major focus is on heuristics and global optimization techniques, thus other techniques are grouped in a single table. These techniques have been adopted from time to time for solving the machine loading problem as shown year wise in Table 3.

Optimization techniques and approaches under the classification of global optimization scheme are discussed in Table 2.

Optimization techniques and approaches not falling under the above classifications are discussed in Table 3.

Table 4 has been formulated on regressive analysis of Tables 1-3, for the analysis of the loading objectives to be fulfilled while solving the loading problem. It is a year-wise tabulation and analysis of the loading objectives. 
Table 2. Review of machine loading problems in FMS based on global optimization algorithms.

\begin{tabular}{|c|c|c|c|c|c|c|c|}
\hline \multicolumn{8}{|c|}{ GLOBAL OPTIMIZATION ALGORITHMS } \\
\hline \multicolumn{8}{|c|}{ a. Deterministic approach } \\
\hline \multicolumn{8}{|c|}{ 1. Branch and bound } \\
\hline Sr. & Year & Researcher Name & Approach & & Objectives & Results & Validation approach \\
\hline 1 & 1986 & $\begin{array}{l}\text { M. Berrada \& } \\
\text { K. E. Stecke [26] }\end{array}$ & $\begin{array}{l}\text { Branch and bound } \\
\text { approach }\end{array}$ & $>$ & Balancing of workload & $\begin{array}{l}\text { Computational results } \\
\text { gives fruitful results }\end{array}$ & $\begin{array}{c}\text { Computational results are } \\
\text { produced and demonstrated } \\
\text { the efficiency of suggested } \\
\text { procedures }\end{array}$ \\
\hline 2 & 1989 & $\begin{array}{c}\text { K. Shankar \& } \\
\text { A. Srinivasulu [27] }\end{array}$ & $\begin{array}{l}\text { Branch \& backtrack } \\
\text { procedure and } \\
\text { Heuristic procedures }\end{array}$ & $>$ & $\begin{array}{l}\text { Maximizing assigned } \\
\text { workload } \\
\text { Maximizing throughput } \\
\text { Minimizing workload } \\
\text { unbalance }\end{array}$ & $\begin{array}{l}\text { Each procedure is } \\
\text { illustrative by numerical } \\
\text { example and results are } \\
\text { with improved } \\
\text { performance }\end{array}$ & $\begin{array}{l}\text { An illustrative numerical } \\
\text { example }\end{array}$ \\
\hline 3 & 1994 & $\begin{array}{l}\text { Y. D. Kim \& } \\
\text { C. A. Yano [28] }\end{array}$ & $\begin{array}{l}\text { New branch and } \\
\text { bond algorithm }\end{array}$ & $>$ & Maximizing throughput & Improved efficiency & $\begin{array}{l}\text { Computational results are } \\
\text { produced and compared } \\
\text { with previous results }\end{array}$ \\
\hline & & & & & 2. Algebraic Geometry & & \\
\hline 4 & 1986 & $\begin{array}{l}\text { T. J. Greene \& } \\
\text { R. P. Sadowski [29] }\end{array}$ & $\begin{array}{l}\text { Mixed integer } \\
\text { programming }\end{array}$ & & $\begin{array}{l}\text { Minimizing make span } \\
\text { Minimizing mean flow } \\
\text { time } \\
\text { Minimizing mean } \\
\text { eness }\end{array}$ & $\begin{array}{l}\text { Explained simple numeric } \\
\text { example }\end{array}$ & a simple numeric example \\
\hline 5 & 1987 & $\begin{array}{l}\text { S.C. Sarin \& } \\
\text { C.S. Chen [30] }\end{array}$ & Mathematical model & & $\begin{array}{l}\text { Minimizing overall } \\
\text { machining cost }\end{array}$ & $\begin{array}{c}\text { Computational results are } \\
\text { reported }\end{array}$ & $\begin{array}{l}\text { Computational results are } \\
\text { compared with literature } \\
\text { results }\end{array}$ \\
\hline 6 & 1990 & $\begin{array}{l}\text { K. M. Bretthauer } \\
\text { \& M. A. } \\
\text { Venkataramanan [31] }\end{array}$ & $\begin{array}{l}\text { Linear Integer } \\
\text { Programming }\end{array}$ & & $\begin{array}{l}\text { Maximizing weighted } \\
\text { sum of number of } \\
\text { operation to machine } \\
\text { assignments }\end{array}$ & $\begin{array}{c}\text { Computational results are } \\
\text { satisfactory with improved } \\
\text { performance }\end{array}$ & $\begin{array}{l}\text { Computational results are } \\
\text { produced }\end{array}$ \\
\hline 7 & 1990 & $\begin{array}{l}\text { H. C. Co, J. S. } \\
\text { Biermann, \& } \\
\text { S.K. Chen [32] }\end{array}$ & $\begin{array}{c}\text { Mixed-integer } \\
\text { programming (MIP) }\end{array}$ & $>$ & Balancing of workloads & $\begin{array}{c}\text { Results were found } \\
\text { practical }\end{array}$ & $\begin{array}{c}\text { Computational results are } \\
\text { produced }\end{array}$ \\
\hline 8 & 1990 & $\begin{array}{l}\text { M. Liang \& } \\
\text { S. P. Dutt [33] }\end{array}$ & $\begin{array}{l}\text { Mixed-Integer } \\
\text { Programming }\end{array}$ & $>$ & $\begin{array}{l}\text { Minimizing production } \\
\text { cost }\end{array}$ & $\begin{array}{l}\text { Demand for change on } \\
\text { optimal solution }\end{array}$ & $\begin{array}{c}\text { An example problem is } \\
\text { solved }\end{array}$ \\
\hline 9 & 1993 & Ming Liang [34] & $\begin{array}{c}\text { Non-linear } \\
\text { programming }\end{array}$ & $>$ & $\begin{array}{l}\text { Maximizing system } \\
\text { output }\end{array}$ & $\begin{array}{l}\text { production cost can be } \\
\text { significantly reduced using } \\
\text { this approach }\end{array}$ & $\begin{array}{c}\text { Computational results with } \\
\text { g an illustrative example is } \\
\text { demonstrated }\end{array}$ \\
\hline 10 & 1994 & Ming Liang [35] & $\begin{array}{c}\text { Non-linear } \\
\text { programming }\end{array}$ & $>$ & $\begin{array}{l}\text { Maximizing system } \\
\text { output } \\
\text { minimizing production } \\
\text { cost }\end{array}$ & $\begin{array}{l}\text { Production cost can be } \\
\text { significantly reduced using } \\
\text { this approach }\end{array}$ & $\begin{array}{c}\text { An illustrative example is } \\
\text { g solved using the suggested } \\
\text { approach }\end{array}$ \\
\hline 11 & 1997 & $\begin{array}{c}\text { V. N. Hsu \& } \\
\text { R. D. Matta [36] }\end{array}$ & $\begin{array}{l}\text { Lagrangian-based } \\
\text { heuristic procedure } \\
\text { (MIP problem } \\
\text { formulation) }\end{array}$ & $>$ & total processing cost & $\begin{array}{l}\text { finds a good loading } \\
\text { solution }\end{array}$ & $\begin{array}{l}\text { iteratively compared } \\
\text { different scenarios }\end{array}$ \\
\hline 12 & 1998 & T. J. Sawik [37] & $\begin{array}{l}\text { Integer programming } \\
\& \text { approximative } \\
\text { lexicographic approach }\end{array}$ & $>$ & $\begin{array}{l}\text { Balancing workloads } \\
\text { Minimizing total } \\
\text { interstation transfer time }\end{array}$ & $\begin{array}{l}\text { Results of computational } \\
\text { experiments are reported }\end{array}$ & $\begin{array}{l}\text { illustrative example and } \\
\text { some results of } \\
\text { computational experiments }\end{array}$ \\
\hline 13 & 1999 & $\begin{array}{l}\text { F. Guerrero, S. } \\
\text { Lozano, T. } \\
\text { Koltai, \& J. } \\
\text { Larranaeta [38] }\end{array}$ & $\begin{array}{l}\text { Mixed-integer linear } \\
\text { program }\end{array}$ & $>$ & Balancing of workload & $\begin{array}{c}\text { New approach to loading } \\
\text { problem }\end{array}$ & $\begin{array}{c}\text { Computational results are } \\
\text { produced }\end{array}$ \\
\hline 14 & 2001 & $\begin{array}{l}\text { N. Kumar \& K. } \\
\text { Shanker [39] }\end{array}$ & $\begin{array}{l}\text { Mixed integer } \\
\text { programming }\end{array}$ & $>$ & Balancing of Workload & $\begin{array}{l}\text { Results are in agreement } \\
\text { with previous findings }\end{array}$ & $\begin{array}{c}\text { Computational results are } \\
\text { compared with the previous } \\
\text { findings }\end{array}$ \\
\hline
\end{tabular}




\section{Continued}

152003 M. A. Gamila \& S. mixed integer Motavalli [40] programming

162004 T. Sawik [41]

172011 M. I. Mgwatua [42]
A. M. Abazari, M

182012 Solimanpur, \& H. Sattari [43]

Linear mathematical
programming $\quad \begin{aligned} & \text { Minimizing System } \\ & \text { unbalance }\end{aligned}$

b. Probabilistic

3. Monte Carlo algorithms

191998 S. K. Mukhopadhyay et al. [44]
Minimizing system imbalance
Mixed integer
programming

Linear Mathematical Programming

Maximizing throughput Minimizing make span

Hybrid tabu search and

202004 R. Swarnkar \& M. K. simulated annealing Tiwari [45]

\section{based heuristic} approach

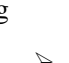
unbalance

Maximizing throughput

Minimizing total (FMC)

212005 M. M. Aldaihani \& M. Savsar [46]

M. K. Tiwari, S. 222006 Kumar, S. Kumar, Prakash, \& R. Shankar [47]

232012

M. Arıkan \& S. Erol [48]

$242000 \quad \begin{gathered}\text { N. Kumar \& K. } \\ \text { Shanker [49] }\end{gathered}$

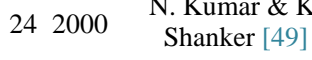

H. Yong \&
Z. Wu [50]
Stochastic model

Constraints-Based Fast $>$ Simulated Annealing (SA) Algorithm

Hybrid simulated annealing-tabu search algorithm flexible manufacturing cell cost per unit of production

Minimizing system unbalance

$>$ Maximizing throughput

Maximizing weighted sum

Minimizing system unbalance

$>$ Balancing of workload

4. Evolutionary Computation (EC)

Evolutionary algorithms (EA)

$>$ Maximizing number of part types in a batch

Genetic algorithm (GA) Maximizing number of parts selected a batch

$>$ Maximizing mean machine utilization

GA-based integrated approach
Balancing of workloads
Results reported increased Computational results are efficiency and performance of system compared with the previous findings

Computational results reported better performance

More interactive decisions and well-balanced

workload of the FMS can be achieved when sub-problems are solved

$$
\text { jointly }
$$

Genetic algorithm (GA) is proposed and performance of proposed GA is

evaluated based on some benchmark problems

Numerical examples and some computational results are compared with available literature

Compared with results from previous literature

Performance is evaluated based on some benchmark problems adopted from the literature
Tried to give global optimum solution

Results reported better performance

\section{Results reported better performance}

Proposed algorithm enjoys the merits of simple SA and simple genetic algorithm

Results shows improved system performance compared to earlier results in literature
Computational results are compared with existing results

Tested on Standard problems and the results obtained are compared with those from some of the existing heuristics from literature

Computational results were presented

The application of the algorithm is tested on standard data sets

The results are compared with those developed earlier by the authors
Results reported reduced computational requirements

Results shows that suggested approach perform better than existing comparative study of Computational results

\section{Computational results are compared with the} previous findings 


\section{Continued}

A. Kumar, Prakash, M. K. Tiwari, R. Shankar, \& A. Baveja [51]

262006

A. Turkcan, M. S

272007 Akturk, \& R. H. Storer [52]

282008 V. Tyagi \& A. Jain [53]

Constraint based genetic algorithm

(CBGA)

U. K. Yusof, R. 292012 Budiarto, \& S. Deris [54]

$\begin{array}{ll}302000 & \text { M. K. Tiwari \& } \\ \text { N. K. Vidyarthi [55] }\end{array}$ Heuristic Approach

M. Yogeswaran, S. 312009 G. Ponnambalam, \& M. K. Tiwari [56]

S. K. Mandal,

322010 M. K. Pandey, \& M. K. Tiwari [57]

V. M Kumar, A.

332012 Murthy, \& K Chandrashekara [58]

342012 C. Basnet [59]

352012 D. Kosucuoglu

\& U. Bilge [60]

362007

S. Biswas \& S. S. Mahapatra [61] parts during production

Better solutions for system
unbalance
The application of the algorithm is tested on standard data sets from available literature. ic algorithm based methodology

Genetic Algorithm
(GA)

manufacturing cost
$>$ Total weighted tardiness machine efficiency \& responsiveness to customer due date requirements

For a given number of tool copies of each tool type

ool loading is affected by the availability of flexible process plans

Genetic Algorithm (GA) based (HA)

Hybrid genetic algorithm simulated annealing algorithm (GASAA) Genetic algorithm simulated annealing nimizing system unbalance

Minimizing system unbalance

Maximizing throughput
Overall combined objective function increased by $3.60 \%$ from previous best result compared with the performance of most commonly used approach in the literature

An illustrative example

tested on 10 sample problems available in the

FMS literature and compared with existing solution methods

Tested on ten sample problems and the computational results obtained have been compared with those of existing methods

results compared with

Results support better Minimising system unbalance

Optimal solution to problem unbalance Maximizing throughput over algorithms reported in reported in the literature literature

Minimizing breakdowns

Minimizing system unbalance

Heuristics approach $>$ Minimizing make span

$>$ Maximizing throughput

Meta-hybrid heuristic technique based on genetic algorithm and particle swarm optimization

Minimizing system unbalance

Maximizing throughput

Hybrid genetic algorithm

Minimizing system unbalance

Genetic algorithm based mathematical programming (GAMP)

Minimizing total distance travelled by

Results incurred under breakdowns validate robustness of developed model for dynamic ambient of FMS

Model efficiency and performance of system is comparable with results compared to literature Swarm Optimization

Computational comparison between the genetic algorithm and previous algorithms is presented

GALP integration works successfully for this hard-to-solve problem

tested through extensive numerical experiments

compared with existing Swarm Optimization Approach
Minimizing system unbalance techniques for ten standard

Results reported improved
system balance problems available in literature representing three different FMS scenarios 


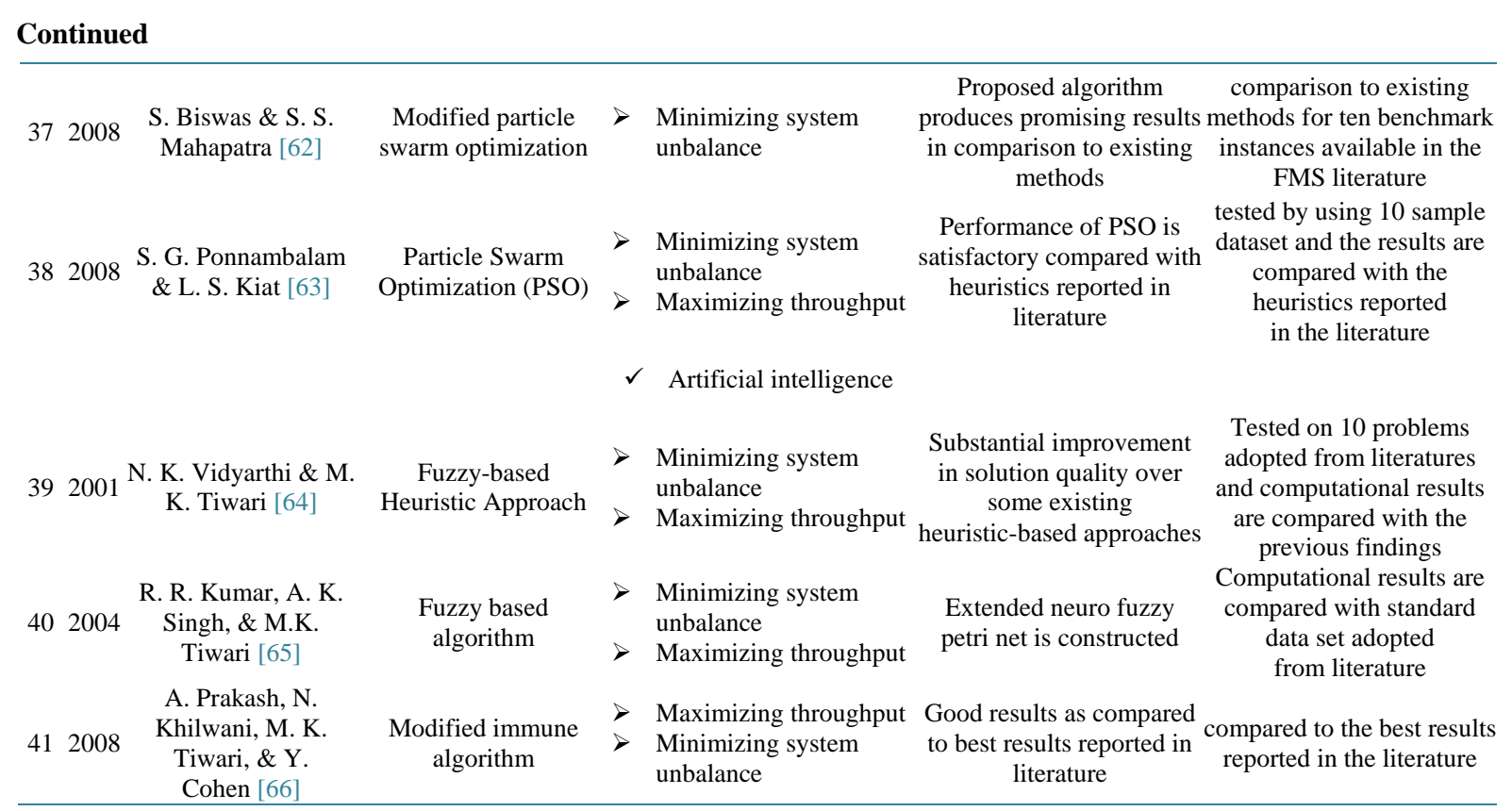

The table is showing the list of objectives for which the loading problem is solved. The tick mark $(\sqrt{ })$ in the table shows the density for repeatability of the objectives.

Abbreviations used in Table 4:

1) Minimizing system unbalance

2) Maximizing throughput

3) Balancing of workload in the system configured of groups composed of machines of equal size

4) Minimizing make span

5) Meeting delivery dates

6) Minimizing manufacturing cost/Minimizing total processing cost/ Minimizing total flexible manufacturing cell cost per unit of production

7) Minimizing tardiness

8) Minimizing production cost

9) Unbalancing the workload per machine for a system of groups of pooled machines of unequal sizes

10) Minimizing part movements

11) Maximizing part types in each batch

12) Minimizing subcontracting costs

13) Maximizing weighted sum of number of operation to machine assignments

14) Minimizing flow time

15) Minimizing late jobs (number)/ lateness

16) Minimizing machine processing time

17) Minimizing production time

18) Filling the tool magazines as densely as possible

19) Maximizing assigned workload

20) Maximizing routing flexibility of batches

21) Maximizing the sum of operations priorities

22) Minimizing material handling time

23) Minimizing total distance travelled by parts during production

24) Minimizing total number of cutting tools required

25) Minimizing workload of machines

26) Minimizing breakdowns

27) Minimizing earliness

After regressive analysis of the loading objectives of various researchers the optimization approaches and 
Table 3. Review of machine loading problems in FMS based on optimization techniques not falling in the above classification.

\section{OTHER OPTIMIZATION TECHNIQUES}

11984 K. E. Stecke \& T. L. Single server closed Morin [67] queueing network model

Balancing of workload

21986 K. E. Stecke [68] Hierarchical approach $>$ Maximizing throughput

31986 J. G. Shanthikumar \& K. E. Stecke [69]

Dynamic approach $>$ Balancing of workload

$41993 \quad$ Y.-D. Kim [70]

Due-Date Based Loading methods

Maximizing throughput tardiness and makespan \&

D. H. Lee, S. K. Lim,

61997 G. C. Lee, H. B. Jun, Iterative algorithms \& Y. D. Kim [72]

Date Based Load- > Minimizing total tardiness

51997 H.-K. Roh \& Y-D. Due-Date Based Minimizing subcontracting costs

71997 Y. D. Kim and C. A. Queueing network Yano [73] model

Maximizing throughput

Maximizing make span

$>$ Balancing of workload

Minimizing earliness

D.-H. Lee \& Y.-D. Kim [74]

Iterative procedures

Minimizing tardiness

Minimizing subcontracting costs

J. N. D. Gupta, L. H.

91999 S. Luong, \& V. H. Dispatching approach Nguyen [75] $102000 \begin{gathered}\text { S. Rahimifard \& S.T. } \\ \text { Newman [76] }\end{gathered}$

W. F. Mahmudy, R.

112012 M. Marian, \& L. H. S. Luong [77]
Minimizing make spans

Minimizing average

flow time

Minimizing tardiness

Combined machine $>$ Meeting delivery dates loading $(\mathrm{CML})>$ Minimising production algorithms

Real coded genetic algorithms (RCGA)
Minimi

Maximizing throughput

Minimizing system unbalance

\section{Maximizes expected production of FMS}

Nonlinear integer programs models

Result maximizes expected production

Results reported reduced in-creased throughput

Iterative approach performs better than others

Results are compared and

contrasted with previous

models of production systems

Ties with some previous results \& use of the proposed models to solve realistic loading problems is discussed

results obtained here complement previous results from literature

Computational tests

Computational tests on randomly generated problems

Solved part selection and loading problems

Reducing number of machine groups and balancing workloads among machines help to reduce make span
Computational experiments on randomly generated test problems are produced
Satisfactory performance of given dispatching algorithm

computational experiments on randomly generated test problems

Computational results are produced

computational experiments are done on randomly generated test problems and the results are compared with existing results

Simulation results are compared with existing results

Adoption of algorithms within an application is dependent on number of manufacturing constraints

Computational results are produced and performance measure is carried out in virtual environment

RCGA improves FMS

performance \& minimizes Results are compared to the required computational previous literature work time

techniques utilized by researchers for problem formulation and its solution are identified and tabulated in Table 3.

The tick marks $(\sqrt{ })$ shows the density of repetitive occurrence of the optimization techniques and approaches for solving the machine loading problem.

Abbreviations used in Table 5:

1) Genetic Algorithm (GA): GA, Hybrid GA, Constraint based GA, Constraint-chromosome GA, Real coded GA, integrated approach based on GA

2) Heuristic Algorithm (HA): HA, Fast HA, Fuzzy based HA, GA based HA, Hybrid TS and SA based HA, Lagrangian based HA, GA and PSO based Meta-hybrid HA, multi stage programming approach based HA 3) Simulated annealing (SA): SA, Constraints-Based Fast SA, GA based SA, Hybrid GA-SA \& SA-TS algorithm 
Table 4. Objectives of machine loading in FMS.

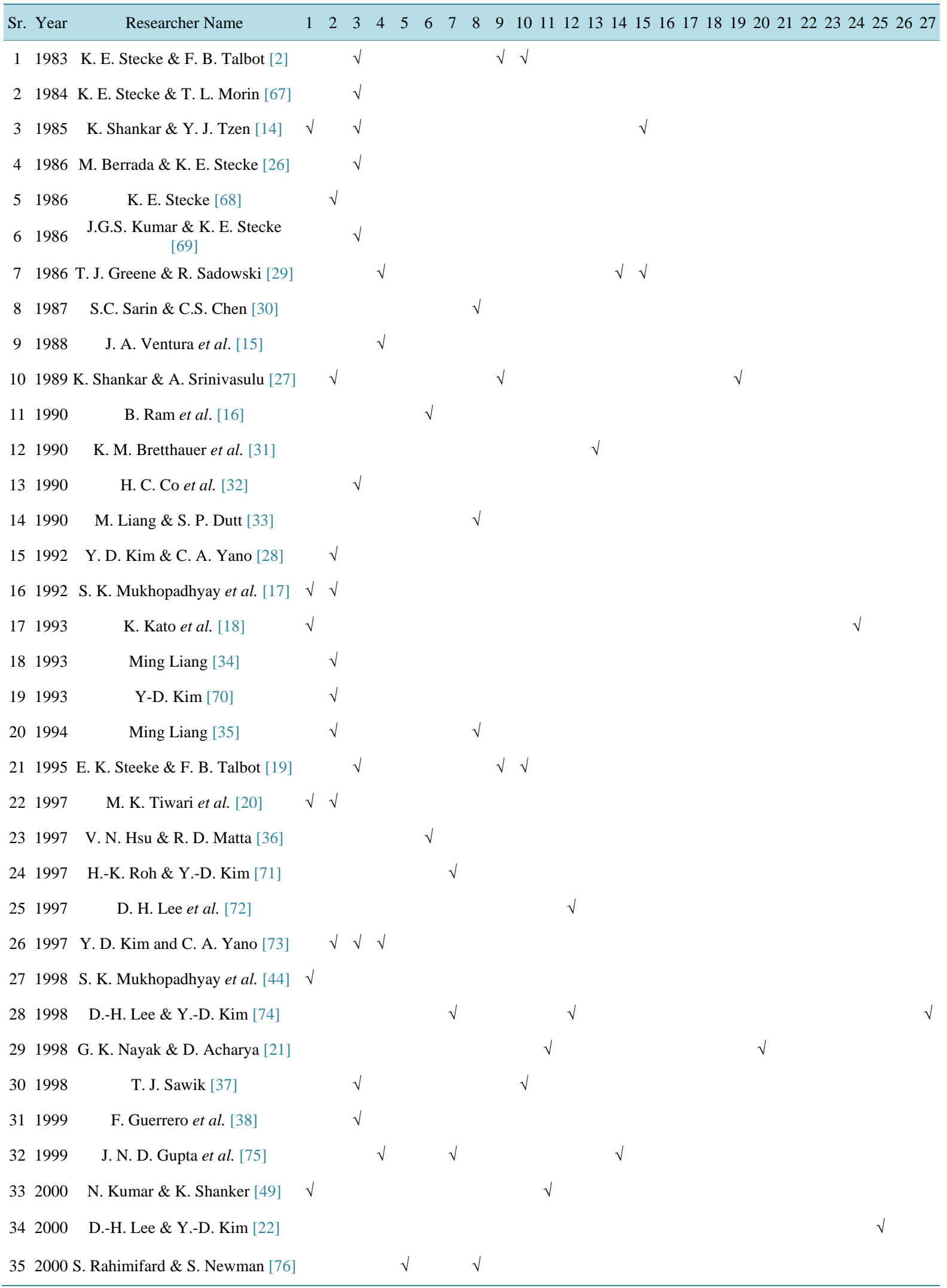




\section{Continued}

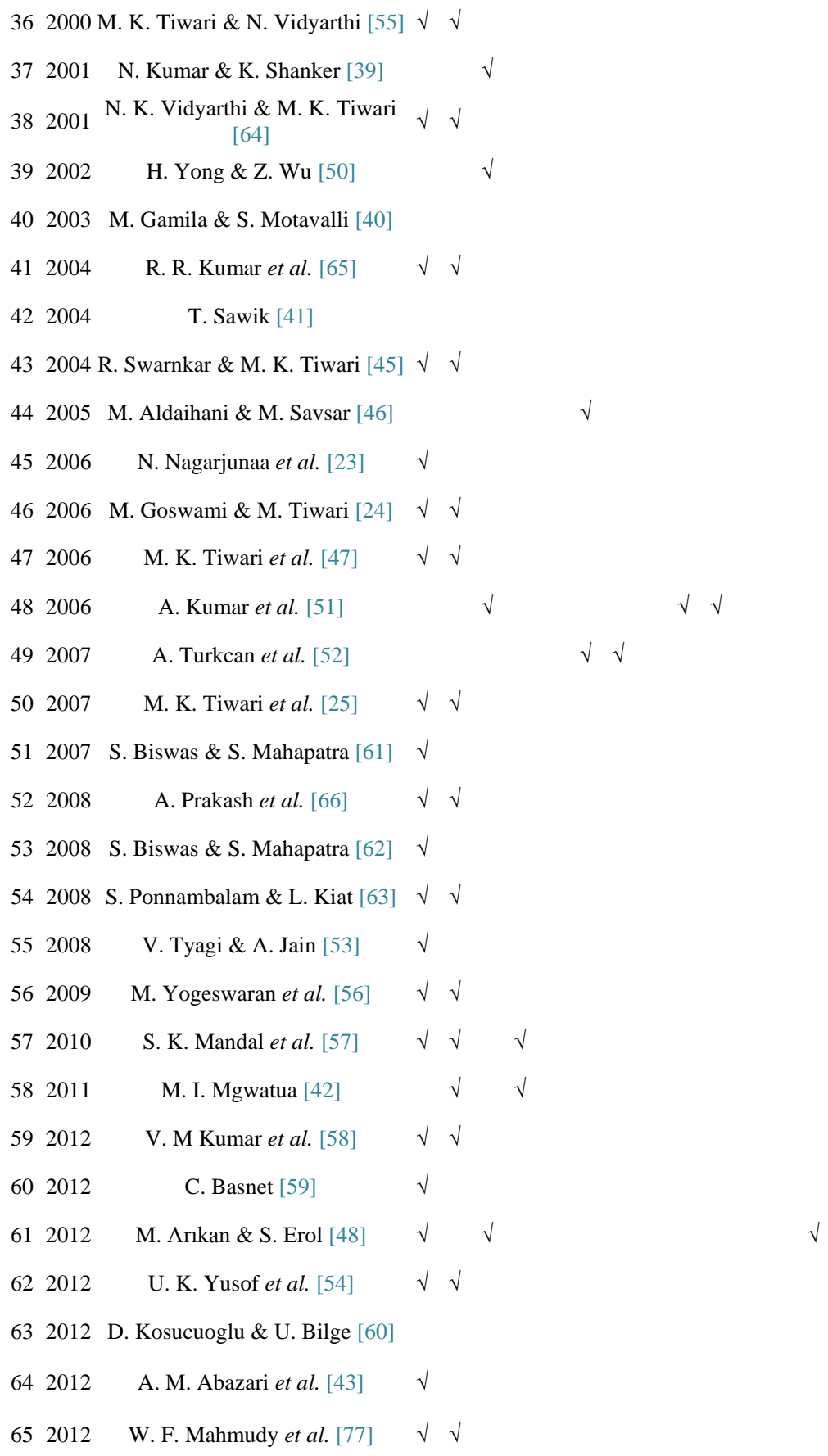

4) Mathematical programming (MP): MP, Linear MP, Non-linear MP, GA based MP

5) Swarm Optimization (SO): SO, Particle SO (PSO), Modified PSO

6) Queueing network model (QNM): QNM, Single server closed QNM

7) Mixed-integer programming (MIP): MIP, GA based MIP

8) Branch and bound algorithms (B\&BA) : B\&BA, New B\&BA

9) Integer programming (IP): IP, linear IP

10) Non-linear programming

11) Stochastic model 
Table 5. Optimization techniques used for solving machine loading problems in FMS.

\begin{tabular}{|c|c|c|c|c|c|c|c|c|c|c|c|c|c|c|c|c|c|c|c|c|c|}
\hline Sr. & Year & Researcher Name & 1 & 2 & 3 & 4 & 5 & 6 & 7 & 8 & 9 & 101 & 1112 & 13 & 14 & 15 & 16 & 17 & 18 & 19 & 2021 \\
\hline 1 & 1983 & K. E. Stecke \& F. B. Talbot [2] & & $\sqrt{ }$ & & & & & & & & & & & & & & & & & \\
\hline 2 & 1984 & K. E. Stecke \& T. L. Morin [67] & & & & & & $\sqrt{ }$ & & & & & & & & & & & & & \\
\hline 3 & 1985 & K. Shankar \& Y. J. Tzen [14] & & $\sqrt{ }$ & & & & & & & & & & & & & & & & & \\
\hline 4 & 1986 & M. Berrada \& K. E. Stecke [26] & & & & & & & & $\sqrt{ }$ & & & & & & & & & & & \\
\hline 5 & 1986 & K. E. Stecke [68] & & & & & & & & & & & & & & $\sqrt{ }$ & & & & & \\
\hline 6 & 1986 & J.G.S. Kumar \& K. E. Stecke [69] & & & & & & & & & & & & & & & & & & & $\sqrt{ }$ \\
\hline 7 & 1986 & T. J. Greene \& R. Sadowski [29] & & & & & & & $\sqrt{ }$ & & & & & & & & & & & & \\
\hline 8 & 1987 & S. C. Sarin \& C. S. Chen [30] & & & & $\sqrt{ }$ & & & & & & & & & & & & & & & \\
\hline 9 & 1988 & J. A. Ventura et al. [15] & & $\sqrt{ }$ & & & & & & & & & & & & & & & & & \\
\hline 10 & 1989 & K. Shankar \& A. Srinivasulu [27] & & $\sqrt{ }$ & & & & & & & & & & & & & $\sqrt{ }$ & & & & \\
\hline 11 & 1990 & B. Ram et al. [16] & & $\sqrt{ }$ & & & & & & & & & & & & & & & & & \\
\hline 12 & 1990 & K. M. Bretthauer et al. [31] & & & & & & & & & $\sqrt{ }$ & & & & & & & & & & \\
\hline 13 & 1990 & H. C. Co et al. [32] & & & & & & & $\sqrt{ }$ & & & & & & & & & & & & \\
\hline 14 & 1990 & M. Liang \& S. P. Dutt [33] & & & & & & & $\sqrt{ }$ & & & & & & & & & & & & \\
\hline 15 & 1992 & Y. D. Kim \& C. A. Yano [28] & & & & & & & & $\sqrt{ }$ & & & & & & & & & & & \\
\hline 16 & 1992 & S. K. Mukhopadhyay et al. [17] & & $\sqrt{ }$ & & & & & & & & & & & & & & & & & \\
\hline 17 & 1993 & K. Kato et al. [18] & & $\sqrt{ }$ & & & & & & & & & & & & & & & & & \\
\hline 18 & 1993 & Ming Liang [34] & & & & & & & & & & $\sqrt{ }$ & & & & & & & & & \\
\hline 19 & 1993 & Y.-D. Kim [70] & & & & & & & & & & & & & & & & & & $\sqrt{ }$ & \\
\hline 20 & 1994 & Ming Liang [35] & & & & & & & & & & $\sqrt{ }$ & & & & & & & & & \\
\hline 21 & 1995 & E. K. Steeke \& F. B. Talbot [19] & & $\sqrt{ }$ & & & & & & & & & & & & & & & & & \\
\hline 22 & 1997 & M. K. Tiwari et al. [20] & & $\sqrt{ }$ & & & & & & & & & & & & & & & & & \\
\hline 23 & 1997 & V. N. Hsu \& R. D. Matta [36] & & $\sqrt{ }$ & & & & & & & & & & & & & & & & & \\
\hline 24 & 1997 & H.-K. Roh \& Y.-D. Kim [71] & & & & & & & & & & & & & & & & & & $\sqrt{ }$ & \\
\hline 25 & 1997 & D. H. Lee et al. [72] & & & & & & & & & & & & & $\sqrt{ }$ & & & & & & \\
\hline 26 & 1997 & Y. D. Kim and C. A. Yano [73] & & & & & & $\sqrt{ }$ & & & & & & & & & & & & & \\
\hline 27 & 1998 & S. K. Mukhopadhyay et al. [44] & & & $\sqrt{ }$ & & & & & & & & & & & & & & & & \\
\hline 28 & 1998 & D.-H. Lee \& Y.-D. Kim [74] & & & & & & & & & & & & & $\sqrt{ }$ & & & & & & \\
\hline 29 & 1998 & G. K. Nayak \& D. Acharya [21] & & $\sqrt{ }$ & & $\sqrt{ }$ & & & & & & & & & & & & & & & \\
\hline 30 & 1998 & T. J. Sawik [37] & & & & & & & & & $\sqrt{ }$ & & & $\sqrt{ }$ & & & & & & & \\
\hline 31 & 1999 & F. Guerrero et al. [38] & & & & & & & $\sqrt{ }$ & & & & & & & & & & & & \\
\hline 32 & 1999 & J. N. D. Gupta et al. [75] & & & & & & & & & & & & & & & & & $\sqrt{ }$ & & \\
\hline 33 & 2000 & N. Kumar \& K. Shanker [49] & $\sqrt{ }$ & & & & & & & & & & & & & & & & & & \\
\hline 34 & 2000 & D.-H. Lee \& Y.-D. Kim [22] & & $\sqrt{ }$ & & & & & & & & & & & & & & & & & \\
\hline 35 & 2000 & S. Rahimifard \& S. Newman [76] & & & & & & & & & & & & & & & & $\sqrt{ }$ & & & \\
\hline
\end{tabular}




\section{Continued}

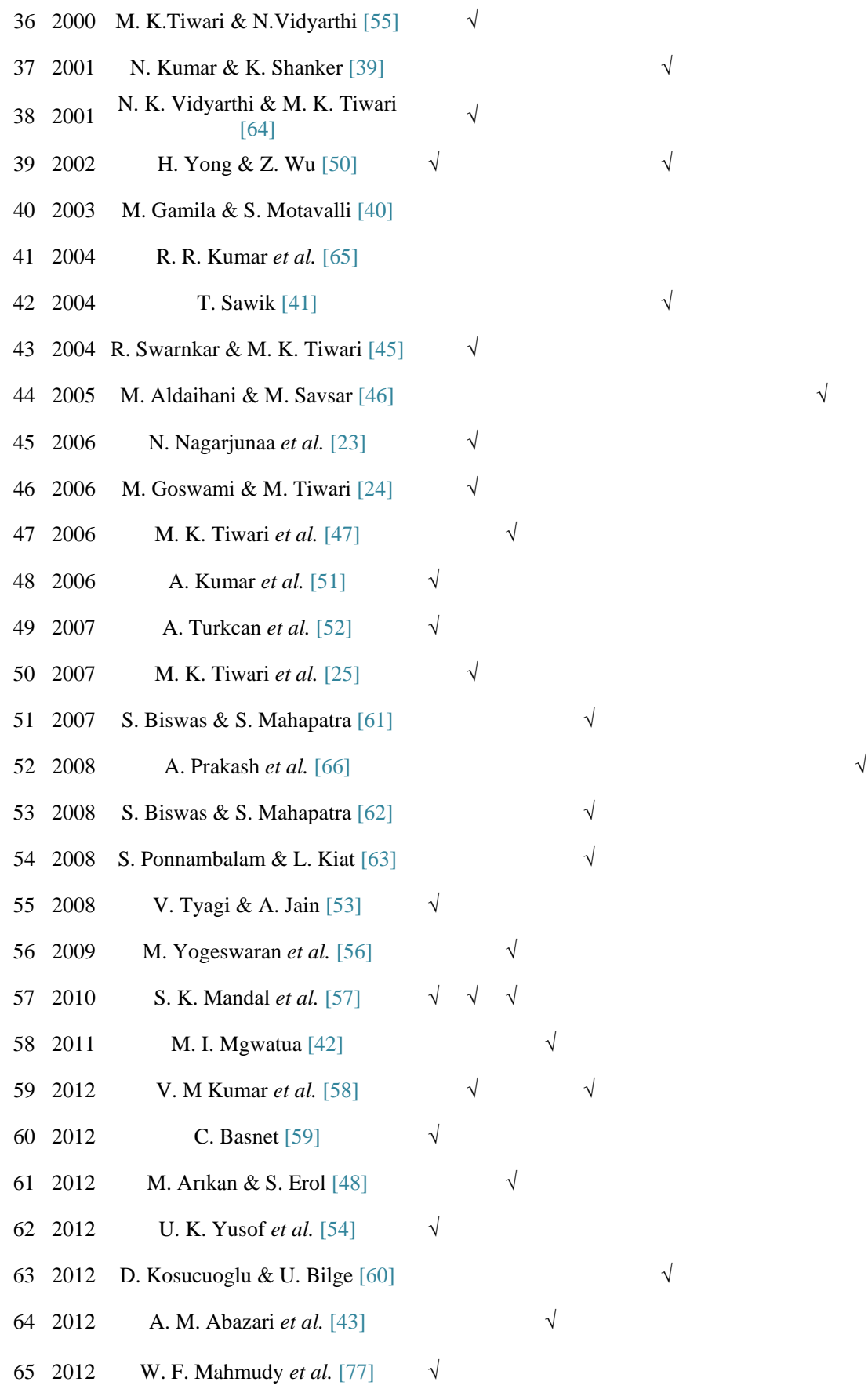

12) Modified immune algorithm

13) Approximative lexicographic approach

14) Iterative algorithms

15) Hierarchical approach

16) Branch \& backtrack procedure

17) Combined machine loading algorithms

18) Dispatching approach

19) Due-Date Based Loading methods 
20) Dynamic approach

21) Fuzzy Logic

\section{Conclusion Arrived on Machine Loading Objectives and Optimization Techniques in FMS}

Detailed study of the machine loading problem is conducted by the authors. The conclusions of the research throttled are divided into three sections as below.

\subsection{Conclusion on Machine Loading Objectives}

On exhaustive study, twenty eight loading objectives are observed in the reviewed literature. Tick marks $(\sqrt{ })$ in Table 4 are showing the density for repeatability of the machine loading objectives, which concludes that a research with maximum loading objectives is still required for solving the machine problem. Maximizing expected production rate (throughput) \& unbalancing the workload per machine for a system of groups of pooled machines of unequal sizes are the two objectives on which most of the researchers have worked. Balancing of workload on machines for a system of groups of pooled machines of equal sizes is the second most researched loading objective. Minimizing make span is the third most researched loading objective. Minimizing job tardiness is fourth loading objective in the order. Minimizing mean job flow time $\&$ minimizing production cost are found at fifth position in the order. Loading objectives observed at sixth rank are maximizing profitability, maximizing the assigned workload, maximizing the part types in each batch, maximizing utilization of system, minimizing subcontracting costs and minimizing the total number of cutting tools required. Material handling time, maximizing routing flexibility of the batches, minimizing earliness, minimizing mean lateness, minimizing mean machine idle time, minimizing overall machining cost, minimizing production time, minimizing the effect of breakdowns, minimizing the maximum workload of the machines, minimizing the number of late jobs, minimizing total flexible manufacturing cell cost per unit of production, minimizing total inter-station transfer time, minimizing total processing time, minimizing part movements and minimisation of the total distance travelled by parts during their production are the loading objectives that are least considered.

\subsection{Conclusion on Optimization Techniques in FMS}

The categorized literature review concludes that the researcher's major emphasis and contribution are towards the use and application of global optimization techniques and with natural optimization techniques, too. Heuristic Algorithms is the mostly used optimization technique by researchers, followed by Genetic Algorithms (GA). Mixed Integer Programming (MIP) \& Simulated Annealing (SA) approach are the third mostly used optimization techniques. Linear Mathematical Programming (LMP) is next in the queue succeeded by Integer Programming (IP). At sixth level is Particle Swarm Optimization (PSO) approach. The least used optimization techniques are Tabu search, Swarm Optimization Approach, Branch and backtrack procedure, Branch and bound approach, Combined machine loading (CML) algorithms, Dispatching approach, Due-Date Based methods, Dynamic approach, Fuzzy Logic, Global criterion approach, Hierarchical approach, Artificial immune algorithm, Iterative algorithms, Lexicographic approach, Non-linear programming, Queueing network model and Stochastic model.

\subsection{Conclusion on validation approaches}

A few research problems are solved and the results are compared with previous research results. The results are validated by comparing with literature available results.

\subsection{Methodologies Findings and Interpretations}

A problem when solved for a limited or less number of objectives, it is rather a customized solution for a problem. For general solution, the problem needs to be solved for all possible objectives. On extreme analysis of the machine loading problem and objectives, and on discussion with the academicians and industrialists, the authors emphasise to solve the loading problem for maximization of throughput, part types in a batch, routing flexibility, balancing/unbalancing of system and workload, and minimization of make-span, delivery dates (covering late- 
ness, tardiness and earliness), part movements, subcontracting costs, machine processing time, tool magazine capacity, number of cutting tools required, breakdowns, non-splitting of jobs, time spend by job on machines in one study. Machine loading problem should be solved for general solution to the problem, for maximum number of objectives. All these objectives are having a common goal of optimizing the production and manufacturing costs.

The literature review reports the application of heuristics, global optimization techniques and some other optimization techniques for solving the loading problem for the listed objectives. Among these approaches, the global optimization techniques were more frequently adopted and the results as founded by the researchers were more accurate and acceptable. Based on regressive analysis of the available literature, and skills and concluding remarks, the authors suggest for the use of natural optimization techniques like swarm optimization for further research. The results of swarm optimization were found more reliable and acceptable as compared to GA, and PSO has attractive characteristics. PSO retains knowledge of all previous particles, which is destroyed in GA when the population changes. PSO is a mechanism of constructive cooperation and information-sharing between particles. Due to the simple concept, ease of implementation, and quick convergence, PSO has gained much attention and has been successfully applied to a wide range of applications.

\section{Research Gaps and Scope of Research in Loading of Machines in FMS}

There exists a research gap among the literature available. There are several future scopes that are still not worked out, or still to be worked in a more optimized manner. Based on our observation and exhaustive study such revealed research gap are listed below: Need of integration of loading with other decisions in the neighbourhood of loading (K. Shankar \& A. K. Agrawal, 1991); need to reduce excessive computing times (Y. D. Kim \& C. A. Yano, 1989); further need of optimization (N. K. Vidyarthi \& M. K. Tiwari, 2001, M. K. Tiwari et al., 2007; Amir Musa Abazari et al., 2012); research is required to develop planning softwares (D. H. Lee et al., 1997); PLC controller needs to be enhanced (M. C. Zhou et al., 1993); waiting time for parts and idling time for machines need attention [Mussa I. Mgwatu, 2011]; research by imposing constraints on the availability of resources i.e. jigs, fixtures, pallets, material handling devices needs to be carried out (K. Kato, 1993, N. K. Vidyarthi \& M. K. Tiwari, 2001; N. Nagarjuna et al., 2006; Akhilesh Kumar et al., 2006; M. K. Tiwari et al., 2007; Sandhyarani Biswas \& S. S. Mahapatra, 2007; Sandhyarani Biswas \& S. S. Mahapatra, 2008; Santosh Kumar Mandal et al. 2010; Amir Musa Abazari et al., 2012); new solution methodology needs to be proposed (Santosh Kumar Mandal et al. 2010); need of AI in the field of FMS ) Chinyao Low et al., 2006; Sandhyarani Biswas \& S. S. Mahapatra, 2008); Need to use dedicated robot (Majid M. Aldaihani \& Mehmet Savsar, 2005); need of simulation studies for FMS (K. Shankar \& A. K. Agrawal, 1991; N. K. Vidyarthi \& M. K. Tiwari, 2001). Availability of a number of research gaps and that too identified by various eminent researchers from time to time evacuates the need of vast research for solving the observed PPC problems i.e. machine loading problems in FMS.

The authors are working to solve the loading problem with more number of objectives in a single study and for the development of knowledge base system for the machine loading problem. The authors suggest for the development of a knowledge base for all five productions planning problems; part type selection problem, machine grouping problem, production ratio problem, resource allocation problem and loading problem in a single study incorporating the individual objectives of the five individual problems and their respective technological and capacity constraints.

\section{References}

[1] Stecke, K.E. (1983) Formulation and Solution of Nonlinear Integer Production Planning Problems for Flexible Manufacturing Systems. Management Science, 29, 273-288. http://dx.doi.org/10.1287/mnsc.29.3.273

[2] Stecke, K.E. and Talbot, F.B. (1983) Heuristic Loading Algorithms for Flexible Manufacturing Systems. Proceedings of the Seventh International Conference on Production Research, Windsor, 22-24 August 1983.

[3] Muhlenbein, H. (1992) Parallel Genetic Algorithms in Combinatorial Optimization. In: Balci, O., Sharda, R. and Zenios, S.A., Eds., Computer Science and Operations Research: New Developments in Their Interfaces, Pergamon Press, Oxford, 441-456.

[4] Russell, S.J. and Norvig, P. (2002) Artificial Intelligence: A Modern Approach. Second Edition, Prentice Hall, Englewood Cliffs.

[5] Rastrigin, L.A. (1963) The Convergence of the Random Search Method in the External Control of Many-Parameter 
System. Automation and Remote Control, 24, 1337-1342.

[6] Metropolis, N., Rosenbluth, A.W., Rosenbluth, M.N., Teller, A.H. and Teller, E. (1953) Equation of State Calculations by Fast Computing Machines. The Journal of Chemical Physics, 21, 1087-1092. http://dx.doi.org/10.1063/1.1699114

[7] Glover, F. (1989) Tabu Search-Part I. Operations Research Society of America (ORSA). Journal on Computing, 1, 90-206. http://dx.doi.org/10.1287/ijoc.1.3.190

[8] Moscato, P. (1989) On Evolution, Search, Optimization, Genetic Algorithms and Martial Arts: Towards Memetic Algorithms. Technical Report C3P 826, Caltech Con-Current Computation Program 158-79, California Institute of Technology, Pasadena.

[9] Holland, J.H. (1962) Outline for a Logical Theory of Adaptive Systems. Journal of the ACM, 9, 297-314. http://dx.doi.org/10.1145/321127.321128

[10] Holland, J.H. and Reitman, J.S. (1977) Cognitive Systems Based on Adaptive Algorithms. ACM SIGART Bulletin, 63, 49. http://dx.doi.org/10.1145/1045343.1045373

[11] Friedberg, R.M. (1958) A Learning Machine: Part I. IBM Journal of Research and Development, 2, 2-13. http://dx.doi.org/10.1147/rd.21.0002

[12] Dorigo, M., Maniezzo, V. and Colorni, A. (1996) The Ant System: Optimization by a Colony of Cooperating Agents. IEEE Transactions on Systems, Man, and Cybernetics Part B: Cybernetics, 26, 29-41. http://dx.doi.org/10.1109/3477.484436

[13] Eberhart, R.C. and Kennedy, J. (1995) A New Optimizer Using Particle Swarm Theory. Proceedings of the Sixth International Symposium on Micro Machine and Human Science, Nagoya, 4-6 October 1995, 39-43. http://dx.doi.org/10.1109/MHS.1995.494215

[14] Shankar, K. and Tzen, Y.J.J. (1985) A Loading and Dispatching Problem in a Random Flexible Manufacturing System. International Journal of Production Research, 23, 579-595. http://dx.doi.org/10.1080/00207548508904730

[15] Ventura, J.A., Chen, F.F. and Leonard, M.S. (1988) Loading Tools to Machines in Flexible Manufacturing Systems. Computers \& Industrial Engineering, 15, 223-230.

[16] Ram, B., Sarin, S. and Chen, C.S. (1990) A Model and Solution Approach for the Machine Loading and Tool Allocation Problem in FMS. International Journal of Production Research, 28, 637-645.

[17] Mukhopadhyay, S.K., Midha, S. and Murlikrishna, V. (1992) A Heuristic Procedure for Loading Problem in Flexible Manufacturing Systems. International Journal of Production Research, 30, 2213-2228. http://dx.doi.org/10.1080/00207549208948146

[18] Kato, K., Oba, F. and Hashimoto, F. (1993) Loading and Batch Formation in Flexible Manufacturing Systems. Control Engineering Practice, 1, 845-850. http://dx.doi.org/10.1016/0967-0661(93)90252-M

[19] Steeke, E.K. and Talbot, F.B. (1995) Heuristics for Loading Flexible Manufacturing Systems, Flexible Manufacturing Systems: Recent Developments. Elsevier Science B.V., Amsterdam, 171-176.

[20] Tiwari, M.K., Hazarika, B., Vidyarthi, N.K., Jaggi, P. and Mukhopadhyay, S.K. (1997) A Heuristic Solution Approach to the Machine Loading Problem of FMS and Its Petri Net Model. International Journal of Production Research, 35, 2269-2284. http://dx.doi.org/10.1080/002075497194840

[21] Nayak, G.K. and Acharya, A.D. (1998) Part Type Selection, Machine Loading and Part Type Volume Determination in FMS Planning. International Journal of Production Research, 36, 1801-1824. http://dx.doi.org/10.1080/002075498192977

[22] Lee, D.H. and Kim, Y.-D. (2000) Loading Algorithms for Flexible Manufacturing Systems with Partially Grouped Machines. IIE Transactions, 32, 33-47.

[23] Nagarjuna, N., Mahesh, O. and Rajagopal, K. (2006) A Heuristic Based on Multi-Stage Programming Approach for Machine-Loading Problem in a Flexible Manufacturing System. Robotics and Computer-Integrated Manufacturing, 22, 342-352. http://dx.doi.org/10.1016/j.rcim.2005.07.006

[24] Goswami, M. and Tiwari, M.K. (2006) A Reallocation-Based Heuristic to Solve a Machine Loading Problem with Material Handling Constraint in a Flexible Manufacturing System. International Journal of Production Research, 44, 569-588.

[25] Tiwari, M.K., Saha, J. and Mukhopadhyay, S.K. (2007) Heuristic Solution Approaches for Combined-Job Sequencing and Machine Loading Problem in Flexible Manufacturing Systems. International Journal of Advanced Manufacturing Technology, 31, 716-730.

[26] Berrada, M. and Stecke, K.E. (1986) A Branch and Bound Approach for Machine Load Balancing in Flexible Manufacturing Systems. Management Science, 32, 1316-1335. http://dx.doi.org/10.1287/mnsc.32.10.1316

[27] Shankar, K. and Srinivasulu, A. (1989) Some Selection Methodologies for Loading Problems in a Flexible Manufac- 
turing System. International Journal of Production Research, 27, 1019-1034. http://dx.doi.org/10.1080/00207548908942605

[28] Kim, Y.-D. and Yano, C.A. (1994) A New Branch and Bound Algorithm for Loading Problems in Flexible Manufacturing Systems. International Journal of Flexible Manufacturing Systems, 6, 361-381. http://dx.doi.org/10.1007/BF01324801

[29] Greene, T.J. and Sadowski, R.P. (1986) A Mixed Integer Programming for Loading and Scheduling Multiple Manufacturing Cells. European Journal of Operation Research, 24, 379-386. http://dx.doi.org/10.1016/0377-2217(86)90031-7

[30] Sarin, S.C. and Chen, C.S. (1987) The Machine Loading and Tool Allocation Problem in a Flexible Manufacturing System. International Journal of Production Research, 25, 1081-1094. http://dx.doi.org/10.1080/00207548708919897

[31] Bretthauer, K.M. and Venkataramanan, M.A. (1990) Machine Loading and Alternate Routing in a Flexible Manufacturing System. Computers and Industrial Engineering, 18, 341-350. http://dx.doi.org/10.1016/0360-8352(90)90056-R

[32] Co, H.C., Biermann, J.S. and Chen, S.K. (1990) A Methodical Approach to the Flexible Manufacturing System Batching, Loading and Tool Configuration Problems. International Journal of Production Research, 28, 2171-2186. http://dx.doi.org/10.1080/00207549008942860

[33] Liang, M. and Dutt, S.P. (1990) A Mixed-Integer Programming Approach to the Machine Loading and Process Planning Problem in a Process Layout Environment. International Journal of Production Research, 28, 1471-1484. http://dx.doi.org/10.1080/00207549008942806

[34] Liang, M. (1993) Part Selection, Machine Loading and Machining Speed Selection in Flexible Manufacturing Systems. Computers and Industrial Engineering, 25, 259-262. http://dx.doi.org/10.1016/0360-8352(93)90270-8

[35] Liang, M. (1994) Integrating Machining Speed, Part Selection and Machine Loading Decisions in Flexible Manufacturing Systems. Computers \& Industrial Engineering, 26, 599-608.

[36] Hsu, V.N. and De Matta, R. (1997) An Efficient Heuristic Approach to Recognize the Infeasibility of a Loading Problem. International Journal of Manufacturing Systems, 9, 31-50.

[37] Sawik, T.J. (1998) A Lexicographic Approach to Bi-Objective Loading of a Flexible Assembly System. European Journal of Operational Research, 107, 656-668. http://dx.doi.org/10.1016/S0377-2217(97)00091-X

[38] Guerreore, F., Lozano, S., Koltai, T. and Larraneta, J. (1999) Machine Loading and Part Type Selection in Flexible Manufacturing System. International Journal of Production Research, 37, 1303-1317. http://dx.doi.org/10.1080/002075499191265

[39] Kumar, N. and Shanker, K. (2001) Comparing the Effectiveness of Workload Balancing Objectives in FMS Loading. International Journal of Production Research, 39, 843-871.

[40] Gamila, M.A. and Motavalli, S. (2003) A Modeling Technique for Loading and Scheduling Problems in FMS. Robotics and Computer Integrated Manufacturing, 19, 45-54.

[41] Sawik, T. (2004) Loading and Scheduling of a Flexible Assembly System by Mixed Integer Programming. European Journal of Operational Research, 154, 1-19. http://dx.doi.org/10.1016/S0377-2217(02)00795-6

[42] Mgwatua, M.I. (2011) Interactive Decisions of Part Selection, Machine Loading, Machining Optimisation and Part Scheduling Sub-Problems for Flexible Manufacturing Systems. International Transaction Journal of Engineering, Management, \& Applied Sciences \& Technologies, 2, 93-109.

[43] Abazari, A.M., Solimanpur, M. and Sattari, H. (2012) Optimum Loading of Machines in a Flexible Manufacturing System Using a Mixed-Integer Linear Mathematical Programming Model and Genetic Algorithm. Computers \& Industrial Engineering, 62, 469-478. http://dx.doi.org/10.1016/j.cie.2011.10.013

[44] Mukhopadhyay, S.K., Singh, M.K. and Srivastava, R. (1998) FMS Loading: A Simulated Annealing Approach. International Journal of Production Research, 36, 1529-1547. http://dx.doi.org/10.1080/002075498193156

[45] Swarnkar, R. and Tiwari, M.K. (2004) Modeling Machine Loading Problem of FMSs and Its Solution Methodology Using a Hybrid Tabu Search and Simulated Annealing-Based Heuristic Approach. Robotics and Computer-Integrated Manufacturing, 20, 199-209. http://dx.doi.org/10.1016/j.rcim.2003.09.001

[46] Aldaihani, M.M. and Savsar, M. (2005) A Stochastic Model for the Analysis of a Two-Machine Flexible Manufacturing Cell. Computers \& Industrial Engineering, 49, 600-610. http://dx.doi.org/10.1016/j.cie.2005.09.002

[47] Tiwari, M.K., Kumar, S., Kumar, S., Prakash and Shankar, R. (2006) Solving Part-Type Selection and Operation Allocation Problems in an FMS: An Approach Using Constraints-Based Fast Simulated Annealing Algorithm. IEEE Transactions on Systems, Man, and Cybernetics_Part A: Systems and Humans, 36, 1170-1184.

[48] Arıkan, M. and Erol, S. (2012) A Hybrid Simulated Annealing-Tabu Search Algorithm for the Part Selection and Machine Loading Problems in Flexible Manufacturing Systems. International Journal of Advanced Manufacturing Tech- 
nology, 59, 669-679. http://dx.doi.org/10.1007/s00170-011-3506-0

[49] Kumar, N. and Shanker, K. (2000) A Genetic Algorithm for FMS Part Type Selection and Machine Loading. International Journal of Production Research, 38, 3861-3887.

[50] Yong, H.H. and Wu, Z.M. (2002) GA-Based Integrated Approach to FMS Part Type Selection and Machine Loading Problem. International Journal of Production Research, 40, 4093-4110. http://dx.doi.org/10.1080/00207540210146972

[51] Kumar, A., Prakash, Tiwari, M.K., Shankar, R. and Baveja, A. (2006) Solving Machine-Loading Problem of a Flexible Manufacturing System with Constraint-Based Genetic Algorithm. European Journal of Operational Research, 175, 1043-1069. http://dx.doi.org/10.1016/j.ejor.2005.06.025

[52] Turkcan, A., Akturk, M.S. and Storer, R.H. (2007) Due Date and Costbased FMS Loading, Scheduling and Tool Management. International Journal of Production Research, 45, 1183-1213.

[53] Tyagi, V. and Jain, A. (2008) Assessing the Effectiveness of Flexible Process Plans for Loading and Part Type Selection in FMS. Advances in Production Engineering \& Management, 3, 27-44.

[54] Yusof, U.K., Budiarto, R. and Deris, S. (2012) Constraint-Chromosome Genetic Algorithm for Flexible Manufacturing System Machine-Loading Problem. International Journal of Innovative Computing, Information and Control, 8, 15911609.

[55] Tiwari, M.K. and Vidyarthi, N.K. (2000) Solving Machine Loading Problem in Flexible Manufacturing System Using Genetic Algorithm Based Heuristic Approach. International Journal of Production Research, 38, 3357-3384. http://dx.doi.org/10.1080/002075400418298

[56] Yogeswaran, M., Ponnambalam, S.G. and Tiwari, M.K. (2009) An Efficient Hybrid Evolutionary Heuristic Using Genetic Algorithm and Simulated Annealing Algorithm to Solve Machine Loading Problem in FMS. International Journal of Production Research, 47, 5421-5448.

[57] Mandal, S.K., Pandey, M.K. and Tiwari, M.K. (2010) Incorporating Dynamism in Traditional Machine Loading Problem: An AI-Based Optimization Approach. International Journal of Production Research, 48, 3535-3559. http://dx.doi.org/10.1080/00207540902814306

[58] Kumar, V.M., Murthy, A.N.N. and Chandrashekar, K. (2012) A Hybrid Algorithm Optimization Approach for Machine Loading Problem in Flexible Manufacturing System. Journal of Industrial Engineering International, 8, 3. http://dx.doi.org/10.1186/2251-712X-8-3

[59] Basnet, C. (2012) A Hybrid Genetic Algorithm for a Loading Problem in Flexible Manufacturing Systems. International Journal of Production Research, 50, 707-718.

[60] Koşucuoglu, D. and Bilge, U. (2012) Material Handling Considerations in the FMS Loading Problem with Full Routing Flexibility. International Journal of Production Research, 50, 6530-6552.

[61] Biswas, S. and Mahapatra, S.S. (2007) Machine Loading in Flexible Manufacturing System: A Swarm Optimization Approach. Proceedings of the Eighth International Conference on Operations and Quantitative Management, Bangkok, 17-20 October 2007.

[62] Biswas, S. and Mahapatra, S.S. (2008) Modified Particle Swarm Optimization for Solving Machine Loading Problems in Flexible Manufacturing Systems. International Journal of Advanced Manufacturing Technology, 39, 931-942.

[63] Ponnambalam, S.G. and Kiat, L.S. (2008) Solving Machine Loading Problem in Flexible Manufacturing Systems Using Particle Swarm Optimization. World Academy of Science, Engineering and Technology, 39, 14-19.

[64] Vidyarthi, N.K. and Tiwari, M.K. (2001) Machine Loading Problem of FMS: A Fuzzy-Based Heuristic Approach. International Journal of Production Research, 39, 953-979. http://dx.doi.org/10.1080/00207540010010244

[65] Kumar, R.R., Singh, A.K. and Tiwari, M.K. (2004) A Fuzzy Based Algorithm to Solve the Machine-Loading Problems of a FMS and Its Neuro Fuzzy Petri Net Model. International Journal of Advanced Manufacturing Technology, 23, 318-341. http://dx.doi.org/10.1007/s00170-002-1499-4

[66] Prakash, A., Khilwani, N., Tiwari, M.K. and Cohen, Y. (2008) Modified Immune Algorithm for Job Selection and Operation Allocation Problem in Flexible Manufacturing Systems. Advances in Engineering Software, 39, 219-232. http://dx.doi.org/10.1016/j.advengsoft.2007.01.024

[67] Stecke, K.E. and Morin, T.L. (1985) The Optimality of Balancing Workloads in Certain Types of Flexible Manufacturing Systems. European Journal of Operational Research, 20, 68-82.

[68] Stecke, K.E. (1986) A Hierarchical Approach to Solving Grouping and Loading Problems of Flexible Manufacturing Systems. European Journal of Operational Research, 24, 369-378. http://dx.doi.org/10.1016/0377-2217(86)90030-5

[69] Shanthikumar, J.G. and Stecke, K.E. (1986) Reducing Work in Progress Inventory in Certain Classes of Flexible Manufacturing Systems. European Journal of Operation Research, 26, 266-271. 
http://dx.doi.org/10.1016/0377-2217(86)90189-X

[70] Kim, Y.-D. (1993) A Study on Surrogate Objectives for Loading a Certain Type of Flexible Manufacturing Systems. International Journal of Production Research, 31, 381-392. http://dx.doi.org/10.1016/0377-2217(86)90189-X

[71] Roh, H.-K. and Kim, Y.-D. (1997) Due-Date Based Loading and Scheduling Methods for a Flexible Manufacturing System with an Automatic Tool Transporter. International Journal of Production Research, 35, 2989-3004.

[72] Lee, D.-H., Lira, S.-K., Lee, G.-C., Jun, H.-B. and Kim, Y.-D. (1997) Multi-Period Part Selection and Loading Problems in Flexible Manufacturing Systems. Computers \& Industrial Engineering, 33, 541-544.

[73] Kim, Y.D. and Yano, C.A. (1997) Impact of Throughput Based Objective and Machine Grouping Decisions on the Short-Term Performance of Flexible Manufacturing System. International Journal of Production Research, 35, 33033322. http://dx.doi.org/10.1080/002075497194084

[74] Lee, D.-H. and Kim, Y.-D. (1998) Iterative Procedures for Multi-Period Order Selection and Loading Problems in Flexible Manufacturing Systems. International Journal of Production Research, 36, 2653-2668. http://dx.doi.org/10.1080/002075498192418

[75] Gupta, J.N.D. (1999) Part Dispatching and Machine Loading in Flexible Manufacturing System Using Central Queues. International Journal of Production Research, 37, 1427-1435. http://dx.doi.org/10.1080/002075499191337

[76] Rahimifard, S. and Newman, S.T. (2000) Machine Loading Algorithms for the Elimination of Tardy Jobs in Flexible Batch Machining Applications. Journal of Materials Processing Technology, 107, 450-458.

[77] Mahmudy, W.F., Marian, R.M. and Luong, L.H.S. (2012) Solving Part Type Selection and Loading Problem in Flexible Manufacturing System Using Real Coded Genetic Algorithms-Part II: Optimization. World Academy of Science, Engineering and Technology, 69, 778-782. 